\title{
Influence of pH in the enzymatic hydrolyzate of concentrates from the fishmeal industry
}

Influencia del pH en el hidrolizado enzimático de concentrados de la industria de harina de pescado

\section{Influência do $\mathrm{pH}$ no hidrolisado enzimático concentrados da indústria de farinha de peixe}

Jairo Corral Palacios ${ }^{1 *}$ (잉 (1)

María Hipatia Delgado-Demera ${ }^{2}$

Carlos Alfredo Cedeño-Palacios ${ }^{3}$

Rev. Fac. Agron. (LUZ). 2022, 39(1): e223904

ISSN 2477-9407

DOI: https://doi.org/10.47280/RevFacAgron(LUZ).v39.n1.04

\section{Food Technology}

Associate editor: Dra. Gretty Ettiene

\begin{abstract}
${ }^{1}$ Maestría en Ingeniería Química, Instituto de Posgrado, Universidad Técnica de Manabí, Av. Urbina y Che Guevara, Portoviejo, Manabí, Ecuador.

${ }^{2}$ Departamento de Veterinaria. Facultad de Ciencias Veterinarias. Universidad Técnica de Manabí, Ecuador.

${ }^{3}$ Departamento de Procesos Químicos. Facultad de Ciencias Matemáticas, Físicas y Químicas. Universidad Técnica de Manabí, Ecuador.
\end{abstract}

Received: 12-02-2021

Accepted: 12-08-2021

Published: 16-12-2021

\section{Keywords:}

Protein

Stickwater

Amino acids

Food additive

Protein hydrolyzate

\begin{abstract}
The fishmeal concentrate is a byproduct that has an important amount of components useful for the food industry. However, if the fishmeal concentrate is not processed, it could cause an imbalance of the environment in which the waste is discharged. The aim of this research was to evaluate the influence of the $\mathrm{pH}$ in the enzymatic hydrolysis of the fishmeal industry for the production of protein concentrates from stickwater as a primary commodity. Thus, the $\mathrm{pH}$ values $(5.32,5.94$ y 6.33$)$ were examinated, also a proximal analysis to hydrolysate and soluble fish was carried out. In order to determine protein, moisture, fats and ashes the following methods were used, Kjeldhal method for protein, rapid thermobalance method for moisture, Soxhlet methos for fats, and official INEN 0467 method for ashes. Protein concentration analyzes were performed by the Bradford method, and subsequently, the hydrolysis approximation was calculated and the amino acid composition was determined by the reference method Waters UPLC. The results showed that the $\mathrm{pH}$ of 6.33 allowed to achieve a better hydrolysis because a higher hydrolysis approximation was obtained, thus also the results obtained from the amino acid composition in the final product demonstrate its potential use as a food additive.
\end{abstract}




\section{2-5 | Rev. Fac. Agron. (LUZ). 2022, 39(1): e223904. January - March. ISSN 2477-9407.}

\section{Resumen}

El concentrado de la industria de la harina de pescado es un subproducto que contiene una gran cantidad de compuestos utilizables en la industria alimentaria. Sin embargo, en el caso de no ser procesados podría causar un desequilibrio en las propiedades físicas, químicas y biológicas del entorno en el cual se realiza la descarga de los desechos. El objetivo del estudio fue evaluar la influencia del $\mathrm{pH}$ en el hidrolizado enzimático de la industria de harina de pescado para la elaboración de concentrados proteínicos a partir de muestras de agua de cola como materia prima. Para la ejecución de esta investigación se evaluaron tres valores de $\mathrm{pH}(5,32 ; 5,94$ y 6,33$)$. Se realizó el análisis proximal al hidrolizado y al soluble de pescado. La determinación de proteína se realizó por el método Kjeldahl, humedad por el método rápido de la termobalanza, grasas por el método Soxhlet y cenizas por el método oficial de la INEN 0467. Se realizaron análisis de concentración de proteína por el método de Bradford, posteriormente, se calculó la aproximación de hidrólisis y se determinó la composición de aminoácidos mediante el método de referencia Waters UPLC. Los resultados mostraron que el $\mathrm{pH}$ de 6,33 permitió alcanzar una mejor hidrólisis debido a que se obtuvo una aproximación de hidrolisis más elevada, así también, los resultados obtenidos de la composición de aminoácidos en el producto final demuestran su potencial uso como aditivo alimenticio.

Palabras clave: Proteína, agua de cola, aminoácidos, aditivo alimenticio, hidrolizado proteico.

\section{Resumo}

O concentrado da indústria da farinha de peixe é um subproduto que contém uma grande quantidade de compostos utilizáveis na indústria alimentar. Contudo, se não for processado, poderá causar um desequilíbrio nas propriedades físicas, químicas e biológicas do ambiente em que os resíduos são descarregados. O objectivo deste estudo foi avaliar a influência do $\mathrm{pH}$ no hidrolisado enzimático na indústria de farinha de peixe para a produção de concentrados de proteínas a partir de amostras de água de cola como matériaprima. Três valores de $\mathrm{pH}(5,32,5,94$ e 6,33$)$ foram avaliados para a execução desta investigação. Foi realizada uma análise proximal do hidrolisado de peixe e peixes solúveis. A proteína foi determinada pelo método Kjeldahl, a humidade pelo método de termobalanço rápido, a gordura pelo método Soxhlet e as cinzas pelo método oficial INEN 0467. A análise da concentração de proteínas foi realizada pelo método de Bradford, depois a aproximação da hidrólise foi calculada e a composição de aminoácidos foi determinada pelo método de referência Waters UPLC. Os resultados mostraram que o pH de 6,33 permitiu alcançar uma melhor hidrólise porque foi obtida uma maior aproximação à hidrólise. Além disso, os resultados obtidos a partir da composição de aminoácidos no produto final demonstram a sua potencial utilização como aditivo alimentar.

Palavras-chave: Proteína, água de cola, aminoácidos, aditivo alimentar, hidrolisado de proteínas.

\section{Introduction}

Currently the demand for fishmeal has increased rapidly, especially in some of the emerging aquaculture countries in Asia, such as China, which is the largest producer and exporter of aquaculture and also the largest. fishmeal consumer worldwide (Han et al., 2018; Li et al., 2019).

Fishmeal is a naturally balanced food ingredient, rich in protein, energy and minerals (Jannathulla et al., 2019), however, during the fishmeal production process the raw material is subjected to a process of pressing, obtaining a mass in which the suspended solids and fish oil are separated by a centrifugation process, producing an effluent commonly called tail water (Wu \& Bechtel, 2012), if the by-product is not used again in the plant, is usually discarded in the environment, causing serious damage to the local fauna and flora (Babazadeh et al., 2014). For this reason, it is necessary to find an efficient method to reuse the by-product and in turn give it added value, making the most of its properties. Tail water evaporated to a thick syrup can provide valuable amounts of protein, soluble solids, vitamins and minerals (Mahdabi \& Hosseini-Shekarabi, 2018). Currently, the by-products of fishmeal production are considered a raw material with a high potential for the production of products instead of being considered a waste (Mahdabi et al., 2018).

According to Wisuthiphaet et al. (2015), one way to use fishmeal by-products is for production of fish protein hydrolyzate. Although this method is more time consuming and has a higher production cost, the fish protein hydrolysates obtained by this method are more nutritional and offer a wide range of applications including animal nutrition or food additives.

The objective of this study was to evaluate the Influence of $\mathrm{pH}$ in the enzymatic hydrolyzate of concentrate from the fishmeal industry for the elaboration of protein concentrates from tail water samples of the marine species Thunnus albacares, Katsuwonus pelamis and Opisthonema libertate.

\section{Materials and methods}

\section{Raw material}

The raw material (tail water obtained from the scrap of tuna from the marine species Thunnus albacares, Katsuwonus pelamis and Opisthonema libertate), was collected from companies producing fishmeal in the city of Jaramijo-Manabí $0^{\circ} 58^{\prime} 34.9^{\prime \prime}$ South and $80^{\circ} 38^{\prime} 14.9$ " West.

\section{Enzyme}

The proteolytic enzyme Granozyme ACC $($ was used for enzymatic hydrolysis. The details of the proteolytic enzyme used in the present study are presented in table 1 .

Table 1. Description of the Granozyme ACC® enzyme.

\begin{tabular}{lc}
\hline \multicolumn{2}{c}{ Specifications } \\
\hline Effective pH range & 6 to 7,5 \\
Effective temperature range & 45 to $60^{\circ} \mathrm{C}$ \\
Shape & Liquid \\
Smell & Typical of the enzyme \\
Density & $1.15 \mathrm{~g} \cdot \mathrm{mL}^{-1}$ \\
Minimal Activity & $840 \mathrm{UHb} \cdot \mathrm{g}^{-1}$ \\
\hline
\end{tabular}

Source: (Granotec, 2017)

\section{Preparation of the enzymatic hydrolyzate}

To obtain the enzymatic hydrolyzate, the tail water was passed through a concentration process in a triple effect evaporating plant, obtaining a liquid with a high concentration of organic matter called concentrate or soluble fish, which must have $40^{\circ}$ Brix. Subsequently, the soluble concentrate passed to a reactor where an $85 \%$ potassium 
hydroxide solution was added, which allowed it to increase the $\mathrm{pH}$ of the concentrate to a value that ranged between 5.5 and 7, (Hanna HI99121 pH-meter). The selected enzyme was added when the temperature in the reactor was $60{ }^{\circ} \mathrm{C}$. Once the enzyme was added, one (1) hour was waited, giving rise to the enzymatic process, in which the proteins were hydrolyzed into peptides and amino acids of lower molecular mass. Simultaneously with the hydrolysis, the stabilizer (Xanthan Gum) was added in a dose of $3.5 \mathrm{~g} . \mathrm{kg}^{-1}$ of product and potassium sorbate was used as preservative, in a dose of 2000 mg. $\mathrm{kg}^{-1}$ of product, to achieve a better homogenization of these with the hydrolyzed product. The Granozyme ACC® enzyme was activated to perform its function and at the end of the reaction it must be inactivated, either by temperature or $\mathrm{pH}$. For which, the entry of steam was opened to the jacket of the reactor to raise the temperature of the hydrolyzate to $90^{\circ} \mathrm{C}$, maintaining it for $15 \mathrm{~min}$. Subsequently, the hydrolyzate was cooled to room temperature. Phosphoric acid was added to the reactor, in a dose of 4 to $5 \%$, obtaining a finished product with a $\mathrm{pH}$ lower than 4.5 . Finally, the product was unloaded in properly cleaned and sealed containers.

\section{Proximal analysis}

The proximal analysis of the enzymatic hydrolyzate and the soluble fish was carried out using the following methods: moisture was determined by the rapid thermobalance method, according to the procedure described in the Official Mexican Standard for the determination of moisture in food (NMX, 1982), the percentage of proteins was calculated using the Kjeldahl method according to the methodology described by the Association of Official Analytical Chemists (AOAC, 2005), fats were determined using the Soxhlet method described in the Ecuadorian Technical Standard 0466 (INEN, 1980a) and ashes were determined by means of the Ecuadorian Technical Standard 0467 (INEN, 1980b).

Determination of protein concentration and hydrolysis approximation

The protein concentration was determined by the method of Bradford (1976), the reading was carried out with a microplate reader (iMark Microplate Absorbance Reader-catalog \# 168-1130) at an absorbance of $595 \mathrm{~nm}$. Protein concentration was calculated using the standard curve for bovine serum albumin. The results were expressed in $\mathrm{mg} \cdot \mathrm{mL}^{-1}$.

The hydrolysis approximation was determined by the following formula:

Hydrolysis approximation $=(1-(\mathrm{A} / \mathrm{B})) \mathrm{X} 100 \quad$ Equation 1

Where A: is the protein concentration after hydrolysis and $\mathrm{B}$ : is the protein concentration before subjecting the concentrate to the hydrolyzing action of the enzyme.

\section{Composition of amino acids}

The amino acid composition was determined using the Waters UPLC reference method for amino acid analysis (Waters, 2021), using ultra-performance liquid chromatography (UPLC), for which an ultra-high-performance liquid chromatograph (Waters Acquity UPLC), equipped with a Waters AccQ-TagTM Ultra column (2.1 mm x $100 \mathrm{~mm}$ ), a mobile phase A AccQ-TagTM Ultra Eluent A1, a mobile phase B AccQ-TagTM Ultra Eluent B and the flow rate was $0.7 \mathrm{~mL} \cdot \mathrm{min}^{-1}$. The sample and column temperatures were 20 and $55^{\circ} \mathrm{C}$, respectively. The amino acids determined were: arginine, histidine, isoleucine, lysine, methionine, phenylalanine, threonine and valine. These amino acids were selected because they are within the nutritional requirements of essential amino acids necessary for the marine species to which the product is directed (shrimp).

Experimental design and statistical analysis

A completely randomized design (DCA) was used with three treatments and three repetitions for each one. Each treatment consisted of a $\mathrm{pH}$ value with a different degree of alkalization at the beginning of each hydrolyzate (5.32, 5.94 and 6.33). For statistical analysis the mean values of the Bradford analysis and the hydrolysis approximation were obtained from three replicates and were used for statistical analysis. The difference between the means of the treatments was calculated using Tukey's multiple range test $(p \leq 0.05)$ using the statistical software SPSS version 23.0 (IBM SPSS Statistics, 2015). Data were expressed as means \pm standard deviation (SD).

\section{Results and discussion}

\section{Proximal composition of fish soluble and hydrolyzate}

The results of the proximal composition of the tail water (AC) and the hydrolyzate with each of the different $\mathrm{pH}^{\prime} \mathrm{s}$ are shown in tables 2 and 3 .

Table 2. Proximal composition of the fish soluble.

\section{Fish soluble}

\begin{tabular}{lcccc} 
pH & Humidity (\%) & Protein (\%) & Ash (\%) & Fat (\%) \\
\hline 5.32 & $54.08 \pm 1.35$ & $32 \pm 0.02$ & $10.98 \pm 0.11$ & $1.70 \pm 0.22$ \\
5.94 & $54.44 \pm 1.31$ & $33 \pm 0.01$ & $10.25 \pm 0.23$ & $1.55 \pm 0.32$ \\
6.33 & $53.98 \pm 1.29$ & $32 \pm 0.04$ & $10.66 \pm 0.15$ & $1.57 \pm 0.06$ \\
\hline
\end{tabular}

The data represent the mean $\pm \mathrm{SD}$

Table 3. Proximal composition of the hydrolyzated.

\begin{tabular}{lcccc}
\hline \multicolumn{5}{c}{ Hidrolizated } \\
pH & Humidity (\%) & Protein (\%) & Ash (\%) & Fat (\%) \\
\hline 5.32 & $49.05 \pm 1.27$ & $34.90 \pm 0.05$ & $14.55 \pm 0.46$ & $1.20 \pm 0.34$ \\
5.94 & $49.60 \pm 1.25$ & $35.00 \pm 0.07$ & $14.20 \pm 0.53$ & $0.90 \pm 0.68$ \\
6.33 & $50.30 \pm 1.29$ & $35.60 \pm 0.11$ & $13.55 \pm 0.22$ & $1.05 \pm 0.01$ \\
\hline
\end{tabular}

The data represent the mean $\pm \mathrm{SD}$

It can be seen that in all three cases there was a decrease in the percentage of fat and moisture, and an increase in the percentage of ash and protein (component of greater nutritional interest). The results obtained in the hydrolyzate are different from those reported in previous studies carried out by Nilsang et al. (2005), Souissi et al. (2007); Ovissipour et al. (2009); See et al. (2011); and Taheri et al. (2013). These variations could be due to the source of the raw material used, the production process or even the season in which the fish were caught. In this regard, Šližyte et al. (2014) indicated that this aspect can be an influencing factor in the quality of the final product.

Protein concentration and hydrolysis approximation

The results of the protein concentration and hydrolysis approximation are shown in table 4 . The statistical analysis showed that there are no statistically significant differences $(\mathrm{p} \leq 0.05)$ in the protein concentration and in the hydrolysis approximation, at values of $\mathrm{pH} 5.32$ and 5.94. However, it can be observed that there is a significant difference $(\mathrm{p} \leq 0.05)$ for a $\mathrm{pH}$ of 6.33 , these results suggest that the $\mathrm{pH}$ has an important effect at the time of hydrolyzing. These results agree with the studies carried out by Baez-Suarez et al. (2016) 


\section{4-5 Rev. Fac. Agron. (LUZ). 2022, 39(1): e223904. January - March. ISSN 2477-9407.}

and Zapata et al. (2019). In addition, it can be observed that the hydrolyzate prepared with a $\mathrm{pH}$ of $6.33 \mathrm{had}$ a higher hydrolysis approach, generating a reduction in concentration, which indicates that the hydrolysis with this treatment was more effective.

Table 4. Protein concentration and hydrolysis approximation.

\begin{tabular}{|c|c|c|}
\hline pH & $\begin{array}{c}\text { Protein concentration } \\
\text { mg.mL } L^{-1}\end{array}$ & $\begin{array}{c}\text { Hydrolysis approximation } \\
(\%)\end{array}$ \\
\hline 5.32 & $2.38 \pm 0.12^{\mathrm{a}}$ & $46 \pm 2.50^{\mathrm{a}}$ \\
\hline 5.94 & $2.64 \pm 0.20^{\mathrm{a}}$ & $40 \pm 4.40^{\mathrm{a}}$ \\
\hline 6.33 & $1.22 \pm 0.14^{b}$ & $72 \pm 3.10^{b}$ \\
\hline
\end{tabular}

${ }^{\mathrm{a}, \mathrm{b}}$ Different letters symbolize statistically significant differences $(\mathrm{p}<0.05)$. The data represent the mean $\pm \mathrm{SD}$

\section{Amino acid composition}

The results of the composition of essential amino acids (EAA) of the enzymatic hydrolyzate using the soluble fish as raw material for its elaboration are shown in table 5. It can be seen that the hydrolyzate using the Granozyme ACC ${ }^{\circledR}$ enzyme had a lower EAA composition than that obtained by Bhaskar et al. (2008) and Ovissipour et al. (2012). These results are as expected, because these studies have used viscera or blood that contain a higher percentage of protein to obtain the hydrolyzate. However, the composition of amino acids obtained meets all the nutritional requirements of EAA of the marine species Marsupenaeus japonicus (Teshima et al., 2002), which is a promising result for the use of this type of byproducts in the supplement industry. nutritional.

Table 5. Essential amino acid composition of the hydrolyzate.

\begin{tabular}{ccccc}
\hline EAA & Hidrolizated & $\begin{array}{c}\text { Bhaskar } \\
\text { et al. } \\
\mathbf{( 2 0 0 8 )}\end{array}$ & $\begin{array}{c}\text { Ovissipour } \text { et } \\
\text { al. } \mathbf{( 2 0 1 2 )}\end{array}$ & $\begin{array}{c}\text { EAA request } \\
\text { (Marsupenaeus } \\
\text { japonicus) }\end{array}$ \\
\hline g.100g-1 & $\mathbf{g . 1 0 0 g ^ { - 1 }}$ & $\mathbf{g . 1 0 0 g ^ { - 1 }}$ & $\mathbf{g . 1 0 0 g}^{-1}$ \\
Arginine & 1.80 & 10.82 & 8.81 & $1.40-1.80$ \\
Histidine & 2.32 & 2.06 & 8.45 & $0.50-0.70$ \\
Isoleucine & 1.40 & 3.6 & 6.93 & $1.10-1.40$ \\
Lisine & 1.92 & 7.07 & 1.87 & $1.70-2.00$ \\
Methionine & 1.36 & 2.02 & 1.48 & $0.60-0.80$ \\
Phenylalanine & 1.36 & 3.53 & 3.85 & $1.30-1.60$ \\
Threonine & 1.52 & 4.02 & 5.9 & $1.10-1.40$ \\
Valine & 1.53 & 4.79 & 8.93 & $1.20-1.50$ \\
\hline
\end{tabular}

EAA: essential amino acids; sample number: 25

\section{Conclusions}

The enzymatic hydrolysis of the soluble fish had a better performance at a $\mathrm{pH}$ of 6.33 ; With the implementation of this value, the performance in obtaining large amounts of protein with this byproduct as raw material could be improved, generating added value to it.

Soluble fish has proven to be a promising source of nutritional supplements for marine species to take advantage of a by-product that would otherwise be discarded causing environmental pollution. However, future studies in various marine species are necessary to determine its efficacy as a food additive or animal nutrition.

\section{Cited literature}

Association of official analytical chemists - AOAC. 2005. Determination of Moisture, Ash, Protein and Fat. Official Method of Analysis of the Association of Analytical Chemists. 18th Ed, Washington DC.

Babazadeh, M., Soltani, M., Soltani, A. \& Asl, M.S. (2014). Production of single cell protein from Stickwater of kilka fish meal factory using Lactobacillus plantarum and Bacillus licheniformis. WALIA Journal, 30(S3), 96-101. https://cutt.ly/jQOKIk8

Baez-Suarez, A.J., Ospina-de-Barreneche, N. y Zapata-Montoya, J.E. (2016). Efecto de temperatura, $\mathrm{pH}$, concentración de sustrato y tipo de enzima en la hidrólisis enzimática de vísceras de Tilapia Roja (Oreochromis spp.). Información Tecnológica, 27(6), 63-76. http://dx.doi.org/10.4067/ S0718-07642016000600007

Bhaskar, N., Benila, T., Radha, C. \& Lalitha, R.G. (2008). Optimization of enzymatic hydrolysis of visceral waste proteins of Catla (Catla catla) for preparing protein hydrolysate using a commercial protease. Bioresource Technology, 99(2), 335-343. https://doi.org/10.1016/j. biortech.2006.12.015

Bradford, M.M. (1976). A rapid and sensitive method for the quantitation of microgram quantities of protein utilizing the principle of proteindye binding. Analytical Biochemistry, 72(1-2), 248-254. https://doi. org/10.1016/0003-2697(76)90527-3

Granotec. (2017). Granozyme ACC®. Nutrición y Biotecnología para la salud. Guayaquil. Ecuador. https://www. granotec.com.ec/

Han, D., Shan, X., Zhang, W., Chen, Y., Wang, Q., Li, Z. \& Mai, K. (2018). A revisit to fishmeal usage and associated consequences in Chinese aquaculture. Reviews in Aquaculture, 10(2), 493-507. https://doi. org/10.1111/raq.12183

IBM Corp. Released 2015. IBM SPSS Statistics for Windows, Version 23.0. Armonk, NY: IBM Corp.

Instituto ecuatoriano de normalización - INEN. 1980a. Norma técnica ecuatoriana NTE INEN 0466: Harina de pescado. Determinación de la materia grasa. https://cutt.ly/bQOK0Xe

Instituto ecuatoriano de normalización - INEN. 1980b. Norma técnica ecuatoriana NTE INEN 0467: Harina de pescado. Determinación de las cenizas. https://cutt.ly/SQOK3GZ

Jannathulla, R., Rajaram, V., Kalanjiam, R., Ambasankar, K., Muralidhar, M. \& Dayal, J.S. (2019). Fishmeal availability in the scenarios of climate change: Inevitability of fishmeal replacement in aquafeeds and approaches for the utilization of plant protein sources. Aquaculture Research, 50(12), 3493-3506. https://doi.org/10.1111/are.14324

Li, X., Dong, S., Zhang, W., Fan, X., Wang, R., Wang, P. \& Su, X. (2019). The occurrence of perfluoroalkyl acids in an important feed material (fishmeal) and its potential risk through the farm-to-fork pathway to humans. Journal of Hazardous Materials, 367, 559-567. https://doi. org/10.1016/j.jhazmat.2018.12.103

Mahdabi, M. \& Hosseini-Shekarabi, S.P. (2018). A Comparative Study on Some Functional and Antioxidant Properties of Kilka Meat, Fishmeal, and Stickwater Protein Hydrolysates. Journal of Aquatic Food Product Technology, 27(7), 844-858. https://doi.org/10.1080/10498850.2018. 1500503

Nilsang, S., Lertsiri, S., Suphantharika, M. \& Assavanig, A. (2005). Optimization of enzymatic hydrolysis of fish soluble concentrate by commercial proteases. Journal of Food Engineering, 70(4), 571-578. https://doi. org/10.1016/j.jfoodeng.2004.10.011

Norma oficial mexicana. NMX-F-428.1982. Normas Oficial Mexicanas para la determinación de humedad en alimentos.

Ovissipour, M., Abedian, A., Motamedzadegan, A., Rasco, B., Safari, R. \& Shahiri, H. (2009). The effect of enzymatic hydrolysis time and temperature on the properties of protein hydrolysates from Persian sturgeon (Acipenser persicus) viscera. Food Chemistry, 115(1), 238242. https://doi.org/10.1016/j.foodchem.2008.12.013

Ovissipour, M., Abedian-Kenari, A., Motamedzadegan, A. \& Nazari, R.M. (2012). Optimization of Enzymatic Hydrolysis of Visceral Waste Proteins of Yellowfin Tuna (Thunnus albacares). Food and Bioprocess Technology, 5(2), 696-705. https://doi.org/10.1007/s11947-010-0357-x

See, S.F., Hoo, L.L. \& Babji, A.S. (2011). Optimization of enzymatic hydrolysis of salmon (Salmo salar) skin by Alcalase. International Food Research Journal, 18(4), 1359-1365. https://cutt.ly/GQOLHOd

Šližyte, R., Carvajal, A.K., Mozuraityte, R., Aursand, M. \& Storrø, I. (2014). Nutritionally rich marine proteins from fresh herring by-products for human consumption. Process Biochemistry, 49(7), 1205-1215. https:// doi.org/10.1016/j.procbio.2014.03.012

Souissi, N., Bougatef, A., Triki-Ellouz, Y. \& Nasri, M. (2007). Biochemical and functional properties of sardinella (Sardinetta aurita) by-product hydrolysates. Food Technology and Biotechnology, 45(2), 187-194. https://hrcak.srce.hr/27772

Taheri, A., Anvar, S.A.A., Ahari, H. \& Fogliano, V. (2013). Comparison the functional properties of protein Hydrolysates from poultry byproducts 
and rainbow trout (Onchorhynchus mykiss) viscera. Iranian Journal of Fisheries Sciences, 12(1): 154-169. https://cutt.ly/AQOLNqu

Teshima, S., Alam, M.S., Koshio, S., Ishikawa, M. \& Kanazawa, A. (2002). Assessment of requirement values for essential amino acids in the prawn, Marsupenaeus japonicus (Bate). Aquaculture Research, 33(6), 395-402. https://doi.org/10.1046/j.1365-2109.2002.00684.x

Waters. (2021). Acquity UPLC H-Class PLUS. UPLC Amino Acid Analysis Solution System Guide. USA.

Wisuthiphaet, N., Kongruang, S. \& Chamcheun, C. (2015). Production of Fish Protein Hydrolysates by Acid and Enzymatic Hydrolysis. Journal of Medical and Bioengineering, 4(6), 466-470. https://doi. org/10.12720 / jomb.4.6.466-470
Wu, T. H. \& Bechtel, P.J. (2012). Screening for low molecular weight compounds in fish meal solubles by hydrophilic interaction liquid chromatography coupled to mass spectrometry. Food Chemistry, 130(3), 739-745. https://doi.org/10.1016/j.foodchem.2011.05.088

Zapata, J. E., Moya, M. \& Figueroa, O.A. (2019). Hidrólisis Enzimática de la Proteína de Vísceras de Trucha Arco Íris (Oncorhynchus mykiss): Efecto del tipo de Enzima, Temperatura, $\mathrm{pH}$ y Velocidad de Agitación. Información Tecnológica, 30(6), 63-72. http://dx.doi.org/10.4067/ S0718-07642019000600063 